Jurnal Gentiaras Manajemen dan Akuntasi

\title{
Pengaruh Disiplin dan Tunjangan Kinerja Terhadap Prestasi Kerja Pegawai Kecamatan Sukarame Provinsi Lampung
}

\section{Andy Fitriyadi Dharmatilaar}

Sekolah Tinggi Ilmu Ekonomi Gentiaras Lampung, Indonesia

*email:ms006zeta2001@yahoo.com

\begin{tabular}{|c|c|}
\hline$A R T I C L E \quad I N F O$ & $A B S T R A C T$ \\
\hline $\begin{array}{l}\text { Artikel History: } \\
\text { Received:January 13, } 2021 \\
\text { Revised: January 31, } 2021 \\
\text { Published: February 9, } 2021 \\
\text { Keywords: } \\
\text { Discipline, Performance } \\
\text { Benefits, Employee }\end{array}$ & $\begin{array}{l}\text { Development in the economic, physical and political dimensions occupies a central position. } \\
\text { Then in the next stage, just pay attention to other dimensions including Human Resources. The } \\
\text { Human Resources dimension should have a central position in accordance with the essence of } \\
\text { national development. So that it attracts the interest of researchers to research further with a } \\
\text { research focus on Discipline, Performance Benefits, and Employee Performance. The } \\
\text { hypothesis formulated is that it is assumed that discipline and performance benefits jointly } \\
\text { affect employee performance. Useful research for the management system of Sukarame } \\
\text { District and its tools in formulating discipline and providing performance allowances, so that } \\
\text { public services will be of higher quality in the future and improve employee performance that } \\
\text { is specifically formed. }\end{array}$ \\
\hline
\end{tabular}

Performance

The sample used in this study amounted to 78 employees. Data collection techniques using observation methods, questionnaires, and documentation. The analytical method uses a quantitative approach with the help of SPSS statistical tools for the calculation of the regression model.

The result of hypothesis testing partially proves that Discipline and Performance Allowances have a relatively moderate effect of $69.8 \%$ on Employee Performance with the Performance Allowance variable as the dominant variable affecting Employee Performance by $69.3 \%$.).

\section{NFO A R T I K EL A B S T RA K}

\section{Riwayat Artikel: \\ Diterima: 13 Januari 2021 \\ Direvisi: 31 Januari 2021 \\ Dipublikasikan: 9 Februari 2021}

Kata kunci:
Disiplin, Tunjangan Kinerja,
Kinerja Pegawai

Pembangunan pada dimensi bidang ekonomi, fisik, dan politik menduduki posisi sentral. Kemudian pada tahap berikutnya baru memperhatikan dimensi lain termasuk Sumber Daya Manusia. Dimensi Sumber Daya Manusia seharusnya memiliki posisi sentral sesuai dengan hakekat pembangunan nasional. Sehingga menarik minat peneliti untuk meneliti lebih lanjut dengan fokus penelitian pada Disiplin, Tunjangan Kinerja, dan Prestasi Kerja Pegawai. Hipotesis yang dirumuskan adalah diduga disiplin dan Tunjangan Kinerja secara bersama sama berpengaruh terhadap Prestasi Kerja pegawai. Penelitian Berguna bagi sistem manajemen Kecamatan Sukarame dan perangkatnya dalam merumuskan Disiplin dan pemberian Tunjangan Kinerja, sehingga pelayanan publiknya akan lebih berkualitas dimasa mendatang dan meningkatkan Prestasi Kerja Pegawai yang dibentuk secara spesifik.

Sampel yang digunakan pada penelitian ini berjumlah 78 pegawai. Teknik pengumpulan data dengan metode observasi, kuesioner, dan dokumentasi. Metode analisis dengan pendekatan kuantitatif dengan bantuan alat statistik SPSS untuk perhitungan model regresi.

Hasil pengujian hipotesis secara parsial membuktikan bahwa Disiplin dan Tunjangan Kinerja memiliki pengaruh yang relatif sedang sebesar 69,8\% terhadap Prestasi Kerja Pegawai dengan variabel Tunjangan Kinerja sebagai variabel dominan yang mempengaruhi Prestasi Kerja Pegawai sebesar $69,3 \%$. 


\section{PENDAHULUAN}

Era reformasi tanpa disadari menimbulkan euforia bagi seluruh lapisan masyarakat, ini tercermin dari sikap perilaku yang kadang berlebihan dari situasi dan porsinya dalam melakukan tugas dan fungsinya. Kondisi ini dapat memperburuk keadaan atau instabilitas dan disintegerasi bangsa, sehingga bergulirlah pemberlakuan disentralisasi atau otonomi daerah dengan undangundang nomor 22 tahun 1999, dan diberlakukan mulai awal 2001 yang merupakan babak sejarah baru bagi Indonesia. Pemberian otonomi daerah tersurat dan tersirat, di dalamnya sangat terkait dengan kualitas pengembangan sumber daya manusia yang pada akhirnya menjadi tanggung jawab daerah tingkat II (Kabupaten/Kota). Sebagaimana dikemukakan dalam pasal 2 UU No.22 Tahun 1999 yang telah dirubah beberapa kali terakhir dengan UU no 25 Tahun 2004 tentang Pemerintah Daerah. Peranan pembangunan khususnya di Bandar Lampung tidak lepas dari peran Kecamatan Sukarame. Kecamatan Sukarame membantu melaksanakan ketugasannya dan dalam pengkoodinasian penyusunan standar pelayanan minimal dan budaya kerja serta indeks kepuasan masyarakat di bidang publik, di daerah tetapi belum mempunyai aksestisitas tinggi untuk menjaring, mengantisipasi permasalahan yang berkembang disebabkan beberapa masalah. Masalah tersebut digambarkan dalam Tabel sebagai Berikut:

Tabel 1. Beberapa Kendala Kecamatan Sukarame

\begin{tabular}{ll}
\hline \multicolumn{1}{c}{ Permasalahan } & \multicolumn{1}{c}{ Penyebab masalah } \\
\hline Penundaan Pekerjaan Harian & Terlambatnya kedatangan para pimpinan \\
Delegasi yang tidak berjalan & $\begin{array}{l}\text { Kurangnya pengetahuan dalam mengetahui } \\
\text { tugas rekan sejawat }\end{array}$ \\
Pembuatan keputusan taktis yang lambat & $\begin{array}{l}\text { Kemampuan mengenal pegawai yang rendah } \\
\text { dari pimpinan }\end{array}$ \\
\hline
\end{tabular}

Sumber : Prereseach Sukarame Kec.

Selain masalah tersebut masalah lain yang juga timbul adalah masalah Tunjangan Kinerja yang dirasakan belum sesuai dengan tugas, fungsi dan tujuan profesionalnya, sehingga dengan Tunjangan Kinerja yang ada pegawai Kecamatan Sukarame terkesan tidak bisa melaksanakan tugasnya dikarenakan terkendala biaya dan digambarkan dalam tabel berikut: 


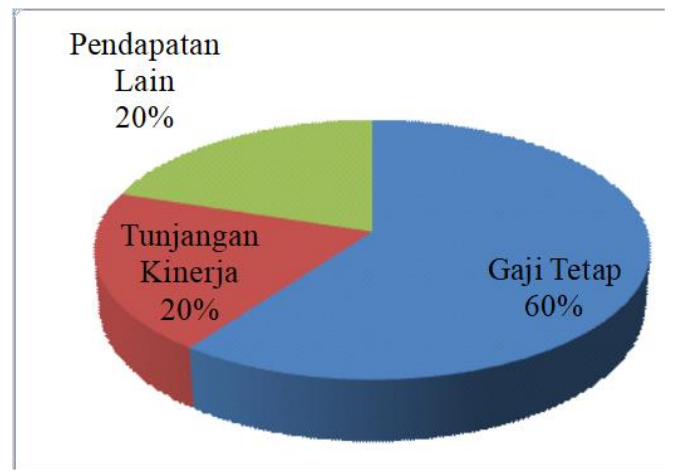

Gambar 1. Komposisi Tunjangan Kinerja Kecamatan Sukarame

Sumber : Prereseach Kecamatan Sukarame

Berdasarkan gambar tersebut diperlihatkan bahwa gaji pokok lebih besar dari Tunjangan Kinerja sehingga pegawai kurang termotivasi dalam bekerja dan hal ini didukung oleh beberapa fakta lapangan tentang kehadiran dan penundaan pekerjaan pegawai yang didapatkan dari Kecamatan Sukarame pada tabel berikut:

Tabel 2. Prestasi Pegawai Selama 6 Bulan Terakhir

\begin{tabular}{|c|c|c|c|c|c|c|}
\hline \multirow[b]{2}{*}{ Bulan } & \multirow[b]{2}{*}{ Tahun } & \multicolumn{3}{|c|}{ Presensi Pegawai } & \multicolumn{2}{|c|}{ Prestasi Pekerjaan } \\
\hline & & $\begin{array}{c}\text { Awal } \\
\text { Masuk } \\
\text { Kerja } \\
\end{array}$ & Terlambat & $\begin{array}{r}\text { Tidak } \\
\text { Masuk } \\
\text { Kerja } \\
\end{array}$ & Selesai & Tunda \\
\hline Juni & 2016 & $55 \%$ & $25 \%$ & $20 \%$ & $70 \%$ & $30 \%$ \\
\hline Juli & 2016 & $52 \%$ & $18 \%$ & $35 \%$ & $65 \%$ & $35 \%$ \\
\hline Agustus & 2016 & $55 \%$ & $17 \%$ & $28 \%$ & $67 \%$ & $33 \%$ \\
\hline September & 2016 & $60 \%$ & $10 \%$ & $30 \%$ & $66 \%$ & $34 \%$ \\
\hline Oktober & 2016 & $55 \%$ & $25 \%$ & $20 \%$ & $62 \%$ & $38 \%$ \\
\hline
\end{tabular}

Sumber : Prereseach Kecamatan Sukarame

Berdasarkan tabel tersebut terlihat bahwa terjadi Fluktuasi jumlah pegawai dan diikuti dengan penurunan jumlah pekerjaan yang diselesaikan pada Kecamatan Sukarame. Pada penelitian awal yang peneliti lakukan di Kecamatan Sukarame tahun 2020 terjadi banyak hal yang menarik minat peneliti untuk meneliti lebih lanjut dengan topik penelitian "Pengaruh Disiplin dan Tunjangan Kinerja Terhadap Prestasi Kerja Pegawai Kecamatan Sukarame”. Fokus penelitian pada Disiplin, Tunjangan Kinerja, dan Prestasi Kerja Pegawai.

Tujuan dibentuknya pemerintahan pada dasarnya adalah berfungsi untuk memberikan pelayanan kepada masyarakat. Ndraha (2009) mengemukakan bahwa pemerintah memiliki dua fungsi dasar, yaitu fungsi primer atau fungsi pelayanan dan fungsi sekunder atau fungsi pemberdayaan. 


\section{DISIPLIN}

Menurut Rivai (2011) Disiplin kerja adalah suatu alat yang digunakan para manajer untuk berkomunikasi dengan pegawai agar mereka bersedia untuk mengubah suatu perilaku serta sebagai suatu upaya untuk meningkatkan kesadaran dan kesediaan seseorang mentaati semua peraturan perusahaan dan norma-norma sosial yang berlaku. Sedangkan menurut Clark (2007) yang dimaksud dengan disiplin adalah bentuk pelatihan yang menjalankan peraturan organisasional. Siagian (2012) menyatakan bahwa pembahasan disiplin pegawai dalam manajemen sumber daya manusia berangkat dari pandangan bahwa tidak ada manusia yang sempurna, lepas dari kesalahan dan kekhilafan. Davis dan Newston dalam Siagian (2012) mengemukakan dua jenis disiplin dalam organisasi, yaitu 1) Disiplin preventif adalah tindakan yang dilakukan untuk mendorong pegawai, mentaati standar dan peraturan sehingga tidak terjadi pelanggaran; 2) Disiplin korektif adalah tindakan yang dilakukan setelah terjadinya pelanggaran peraturan, tindakan ini dimaksudkan untuk mencegah timbulnya pelanggaran lebih lanjut.

Menurut Nimran dalam Masaong (2011), bekerja itu penting untuk menghidupi kehidupan sendiri, sekaligus menjamin rasa berguna, dikehendaki, dibutuhkan dan yang pasti memberi arti bagi kehidupan.

Davis (2008) mengatakan, bahwa disiplin adalah kesediaan dan kesadaran seseorang mentaati semua peraturan perusahaan dan norma-norma sosial yang berlaku. Jika para pegawai itu memahami arti pentingnya bekerja, dapat dipastikan akan melaksanakan tugas-tugas dengan penuh kesadaran atau loyalitas yang tinggi, tumbuh dari dalam dirinya sendiri dan tidak merasa dipaksakan untuk bekerja. Terdapat empat perspektif daftar yang menyangkut disiplin kerja yaitu Disiplin Retributif (Retributive Discipline), yaitu berusaha menghukum orang yang berbuat salah; Disiplin Korektif (Corrective Discipline), yaitu berusaha membantu pegawai mengoreksi perilakunya yang tidak tepat; Perspektif hak-hak individu (Individual Rights Perspective), yaitu berusaha melindungi hak-hak dasar individu selama tindakan-tindakan disipliner; Perspektif Utilitarian (Utilitarian Perspective), yaitu berfokus kepada penggunaan disiplin hanya pada saat konsekuensi-konsekuensi tindakan disiplin melebihi dampak-dampak negatifnya (Handoko, 2015).

Dalam Penelitian ini konsep disiplin didefinisikan sebagai "Kesediaan dan kesadaran seseorang mentaati semua peraturan organisasi dan norma-norma sosial yang berlaku" Davis (2008). Kemudian beberapa indikator yang digunakan untuk mengukur disiplin dalam organisasi, yaitu: 1) Disiplin preventif adalah tindakan yang dilakukan untuk mendorong pegawai, mentaati standar dan peraturan sehingga tidak terjadi pelanggaran; 2) Disiplin korektif adalah tindakan yang 
dilakukan setelah terjadinya pelanggaran peraturan, tindakan ini dimaksudkan untuk mencegah timbulnya pelanggaran lebih lanjut (Siagian, 2012).

\section{TUNJANGAN KINERJA}

Berkaitan dengan hal tersebut perlu diadakan penelitian mengenai variabel yang berpengaruh terhadap motivasi dan Prestasi Kerja pegawai. Dubrin (2015). Clark (2007) menyatakan bahwa Tunjangan Kinerja itu terbagi atas dua pilihan, terdapat Tunjangan Kinerja langsung dan Tunjangan Kinerja tidak langsung. Tunjangan Kinerja langsung terdiri dari gaji, uang transport, tunjangan hari raya, uang lembur, dan tunjangan langsung lainnya. Sedangkan Tunjangan Kinerja tidak langsung terdiri dari promosi jabatan, asuransi, tunjangan jabatan, dan mutasi.

Tunjangan Kinerja merupakan salah satu fungsi yang penting dalam Manajemen Sumber Daya Manusia (MSDM), hal ini sesuai dengan pendapat Luthans (2005:147), memberikan penjelasan tunjangan Kinerja, pada akhir daur motivasi didefinisikan sebagai segala sesuatu yang akan meringankan kebutuhan dan mengurangi gerakan, dengan demikian pencapaian Tunjangan Kinerja akan menuju kepada perbaikan keseimbangan fisiologis dan psikologis dan akan mengurangi atau menghilangkan gerakan. Memakan makanan, meminum air, dan memperoleh teman akan menuju kepada perbaikan keseimbangan dan mengurangi penyesuaian gerakan, makan, air, dan teman adalah Tunjangan Kinerja dari contoh-contoh diatas Tunjangan Kinerja menurut Jones dalam Luthans (2005): bases pay on production ( i.e., printers delwered or revenue targets achieved) healt insurance and social security

Davis dan Newston (2014:135) mengemukakan bahwa Tunjangan Kinerja mengingatkan antara prestasi individu, kelompok atau organisasi yaitu dapat meliputi: upah potongan, komisi, bonus, bagi laba dan bagi produksi. Sedangkan Siagian (2012:265) mengemukakan bahwa sistem Tunjangan Kinerja digolongkan kedalam: (1) Sistem Tunjangan Kinerja pada tingkat individu (Peacework, bonus, komisi, kurva kematangan, dan Tunjangan Kinerja bagi para eksekutif), (2) Sistem Tunjangan Kinerja pada kelompok (Tunjangan Kinerja produksi, bagian keuntungan, dan pengurangan biaya). Selanjutnya Robin (2010:246) mengemukakan Tunjangan Kinerja yang mengandung pengertian yang sama dengan upah variabel yaitu suatu bagian dari upah seseorang karyawan yang didasarkan pada suatu ukuran Prestasi Kerja individual atau organisasi. Upah variabel tersebut terdiri dari upah berdasarkan potongan, bonus, berbagai laba dan berbagai hasil. Dari berbagai pendapat tersebut dapat disimpulkan bahwa sistem Tunjangan Kinerja adalah Tunjangan Kinerja yang diberikan kepada pegawai atas dasar Prestasi Kerja pegawainya. Sistem 
Tunjangan Kinerja tersebut meliputi: (1) Upah potongan (piecework), (2) Komisi, (3) Bonus, (4) Bagian laba, (5) Bagi produksi.

Dalam penelitian ini konsep Tunjangan Kinerja yang merupakan turunan konsep dari (Robin, 2010) mengandung pengertian yang sama dengan upah variabel yaitu "Bagian dari upah seseorang karyawan yang didasarkan pada suatu ukuran beban kerja individual", Upah variabel tersebut terdiri dari upah berdasarkan potongan, bonus, berbagai laba dan berbagai hasil. Dengan indikator konsep Tunjangan Kinerja langsung, dan Tunjangan Kinerja tidak langsung

\section{PRESTASI KERJA}

Berkaitan dengan penelitian yang akan dilakukan, maka peran dari individu sangat menentukan, sehingga uraian mengenai keefektifan hanya akan dibahas pada tingkat individu Robin, (2010).

Prestasi Kerja pegawai pegawai administratif yang hasil pekerjaannya tidak dapat diukur secara kulitatif absolut, maka dapat digunakan pendekatan melalui tiga komponen, Kualitas kerja, yaitu penyelesaian pekerjaan yang dikaitkan dengan ketelitian, kecermatan, kesesuaian standar dan lain sebagainya; Kuantitas kerja, yaitu penyelesaian pekerjaan yang dikaitkan dengan waktu, volume pekerjaan, lembur dan sebagainva; Tanggung jawab, yaitu penyelesaian pekerjaan yang dikaitkan dengan skill, inisiatif, disiplin dalam mengikuti tata kerja yang ada dan lain sebagainya (Greenberg yang dikutip oleh Siagian 2012:88).

Hasil penilaian tersebut dapat saja dimanfaatkan oleh organisasi sebagai dasar untuk mempromosikan pegawai yang dipandang mempunyai Prestasi Kerja pegawai bagus atau untuk kepentingan yang sifatnya untuk kemajuan organisasi. Secara rinci Davis (2008 ; 71) yang mengutip Bellows berpendapat bahwa tujuan dilakukan penilaian Prestasi Kerja pegawai bagi pegawai adalah sebagai dasar penetapan gaji/upah/bonus; sebagai alat dalam pengawasan penugasan pekerjaan; sebagai alat dalam rencana pelatihan; sebagai dasar pemberian nasehat kepada pegawai; dan sebagai alat pemberian perangsang.

Sejalan dengan itu Becker, Huselid, dan Ulrich dalam Clark (2007) mengemukakan dua hal penting dalam mengukur Prestasi Kerja sumber daya manusia dengan menggunakan Human Resources Scorecard (HR-Scorecard), yaitu (1) mengelola sumber daya manusia yang merupakan asset stratejik, (2) memperlihatkan kontribusi sumber daya manusia pada keberhasilan finansial perusahan. 
Kemudian Becker, Huselid, dan Ulrich dalam Clark (2007) mengajukan empat elemen untuk mengukur Prestasi Kerja sumber daya manusia dengan menggunakan HR-Scorecard, yaitu (1) high performance work system, (2) HR system alignment, (3) HR efficiency, dan (4) HR deliverables.

Dalam Penelitian ini Prestasi Kerja pegawai mengutip konsep turunan yang Siagian (2012) yang didefinisikan sebagai "Kemampuan pegawai dalam memberikan kemampuannya pada organisasi untuk dapat mencapai tujuan atau sasaran organisasi." Dengan indikator pencapaian konsep adalah penilaian secara kebetulan; metode tradisional yang sistematis; dan management by objective.

Penelitian ini bertujuan dan menitik beratkan untuk mengetahui pengaruh pada disiplin, tunjangan kinerja, dan prestasi kerja pegawai yang diterjemahkan untuk mengetahui pengaruh disiplin terhadap prestasi kerja pegawai pada kecamatan sukarame, mengetahui pengaruh tunjangan kinerja terhadap prestasi kerja pegawai pada kecamatan sukarame, dan mengetahui pengaruh disiplin dan tunjangan kinerja terhadap prestasi kerja pegawai pada kecamatan sukarame

\section{METODE PENELITIAN}

\section{Jenis Penelitian}

Jenis Penelitian ini adalah evaluasi dengan metode analitik korelasional, untuk menjelaskan secara sistematik fakta atau karakteristik populasi tertentu secara cermat, sesuai dengan pendapat Kerlinger ( Sugiono; $2010: 3$ ), untuk mengukur dan analisis sejauh mana atau seberapa besar pengaruh Disiplin dan Tunjangan Kinerja terhadap Prestasi Kerja.

\section{Metode Pengumpulan Data}

Dalam penelitian ini data yang diperlukan dalam penelitian ini meliputi: Data Primer, yakni data yang diperoleh langsung melalui penelitian, baik melalui penggunaan kuesioner maupun wawancara; Data skunder, data yang diperoleh dari teknik dokumentasi dengan memanfaatkan sumber-sumber yang berkaitan dan dapat mendukung obyek yang akan diteliti dengan metode observasi dan Studi Kepustakaan dan Dokumentasi (Sugiono, 2010).

\section{Metode Pengambilan Sampel}

Unit Analisis adalah satuan tertentu yang diperhitungkan sebagai subyek penelitian, dengan demikian, unit analisis dalam penelitian ini adalah keseluruhan pegawai Kelurahan Sukarame Kecamatan Sukarame Kabupaten Lampung Utara. beserta perangkatnya (Arikunto, 2012 : 13 ). 
Populasi adalah jumlah keseluruhan dari unit analisis yang bagiannya akan digunakan dalam penelitian (Haryono, 2007). Dengan demikian Populasi dalam penelitian ini adalah keseluruhan pegawai Kelurahan Sukarame Kecamatan Sukarame Kabupaten Lampung Utara beserta perangkatnya. Berhubung jumlah populasi relatif kecil, maka peneliti tidak mengadakan atau melakukan penarikan sampel untuk diteliti, karena dapat di jangkau seluruhnya. Hal ini berarti seluruh pegawai Kelurahan Sukarame Kecamatan Sukarame Kabupaten Lampung Utara menjadi responden atau sumber data (sampel jenuh) dalam penelitian ini dengan cara penyebaran kuesioner.

\section{Metode Analisis}

Regresi dan korelasi; keduanya mempunyai pengaruh, dan atau hubungan erat. Setiap regresi pasti ada korelasinya, tetapi korelasi belum tentu dilanjutkan dengan regresi. Korelasi yang tidak dilanjutkan dengan regresi adalah korelasi antara dua variabel yang tidak mempunyai hubungan sebab akibat atau hungungan fungsioal, analisis regresi dilakukan bila hubungan dua variabel berupa hubungan sebab akibat (Haryono, 2007). Penelitian ini dilakukan untuk mengetahui pengaruh model pada masing-masing variabel independen, terhadap variabel dependen menggunakan regresi berganda dengan metode menurut Arikunto, (2012).

\section{HASIL DAN PEMBAHASAN}

Setelah uji Validitas, Reliabilitas, dilakukan pada instrumendan dinyatakan berhasil maka uji Normalitas dan Homogenitas dilakukan dan terpenuhi maka data siap untuk dilakukan uji regresi berganda guna pembuktian hipotesis penelitian. Hasil uji regresi linear berganda yang dilakukan dengan menggunakan program SPSS dengan acuan hasil perhitungan analisis statistik data dijelaskan sebagai model persamaan regresi untuk fungsi ini adalah :

$$
\mathrm{Y}=\alpha+\mathrm{B}_{1} \mathrm{X}_{1}+\mathrm{B}_{2} \mathrm{X}_{2}
$$

diterjemahkan dalam penelitian Prestasi Kerja (Y), Disiplin $\left(\mathrm{X}_{1}\right)$, Tunjangan Kinerja $\left(\mathrm{X}_{2}\right)$, konstanta $(\alpha)$, dan koefisien regresi $\left(B_{1}, B_{2},\right)$.

Acuan hasil tersebut dapat diguankan sebagai panduan dalam mengartikan hasil dari pengolahan data dan Hasil diperoleh model regresi linier baik parsial ataupun berganda adalah sebagai berikut : 
Tabel 3. Hasil Analisis Hipotesis

Model Summary

\begin{tabular}{|c|c|r|r|r|}
\hline Model & $\mathrm{R}$ & R Square & \multicolumn{1}{|c|}{$\begin{array}{c}\text { Adjusted R } \\
\text { Square }\end{array}$} & $\begin{array}{c}\text { Std. Error of } \\
\text { the Estimate }\end{array}$ \\
\hline 1 &, $835^{\mathrm{a}}$ &, 698 &, 690 &, 41251 \\
\hline
\end{tabular}

a. Predictors: (Constant), Tunjangan Kinerja, Disiplin

b. Dependent Variable: Prestasi Kerja Pegawai

\begin{tabular}{|c|c|c|c|c|c|c|}
\hline \multicolumn{7}{|c|}{ ANOVA $^{b}$} \\
\hline & & $\begin{array}{l}\text { Sum of } \\
\text { Squares }\end{array}$ & df & Mean Square & $\mathrm{F}$ & Sig. \\
\hline \multirow[t]{3}{*}{1} & Regression & 29,456 & 2 & 14,728 & 86,551 &, $000^{\mathrm{a}}$ \\
\hline & Residual & 12,762 & 75 & , 170 & & \\
\hline & Total & 42,218 & 77 & & & \\
\hline
\end{tabular}

a. Predictors: (Constant), Tunjangan Kinerja, Disiplin

b. Dependent Variable: Prestasi Kerja Pegawai

Coefficients $^{a}$

\begin{tabular}{|c|c|c|c|c|c|c|}
\hline \multirow{2}{*}{\multicolumn{2}{|c|}{ Model }} & \multicolumn{2}{|c|}{ Unstandardized Coefficients } & \multirow{2}{*}{$\begin{array}{c}\begin{array}{c}\text { Standardized } \\
\text { Coefficients }\end{array} \\
\text { Beta }\end{array}$} & \multirow[b]{2}{*}{$\mathrm{t}$} & \multirow[b]{2}{*}{ Sig. } \\
\hline & & $B$ & Std. Error & & & \\
\hline \multirow[t]{3}{*}{1} & (Constant) & 23,666 & ,485 & & 48,817 &, 000 \\
\hline & Disiplin & 044 & 039 & , 195 & 3,136 & ,026 \\
\hline & Tunjangan Kinerja & ,273 & 072 & 651 & 3,798 &, 000 \\
\hline
\end{tabular}

a. Dependent Variable: Prestasi Kerja Pegawai

Sumber: Hasil Oleh Data SPSS

Berdasarkan hasil uji tersebut maka didapatkan persamaan model regresi yang sebagai berikut :

$$
\begin{array}{ll}
\mathrm{Y} & =23.666+0.044 \mathrm{X} 1+0.273 \mathrm{X} 2 \\
\mathrm{t}_{\text {hitung }} & =(48.817) \\
\mathrm{R}^{2} & =0,698 \\
\mathrm{~F} & =86.551 \text { (Prob.sig }=0,000) \\
\mathrm{N} & =78
\end{array}
$$

Dari hasil regresi yang telah didapat, maka dapat hasil penelitian dapat diinterpretasikan pada diketahui bahwa nilai $\mathrm{F}$ signifikansi adalah $0.035<0.05$ yaitu pada tingkat signifikansi $95 \%$ yang berarti sahih. Dengan demikian maka Ho ditolak, berarti koefisien regresi signifikan dan menerima asumsi linieritas. Kemudian pada uji t yang dilakukan untuk melihat besarnya pengaruh secara individu variabel bebas terhadap variabel tak bebas. Dan hasil estimasi dapat kita lihat bahwa nilai t hitung untuk variabel $(X 1)$ sebesar 3.136 (Prob.sig. $=0,000)$ dan untuk variabel $(X 2)$ sebesar 3.798 (Prob.sig. $=0,000$ )yang berarti t hitung $>\mathrm{t}$ table dengan tingkat signifikansi 95\% (persen). Hal ini menunjukkan bahwa koefisien masing variabel bebas adalah penting secara statistik pengaruhnya terhadap variabel tak bebasnya atau dengan kata lain bahwa berpengaruh Signifikan 
baik secara parsial maupun simultan. Kemudian koefisien determinasi X1 X2 - Y $\left(\mathrm{R}^{2}\right)$ relatif sedang yaitu 0.698 Berarti bahwa 69,8\% (persen) dari variasi perubahan pengaruh Disiplin dan Tunjangan Kinerja dapat menjelaskan Prestasi Kerja Pegawai. Sedangkan 30.2\% (persen) sisanya adalah pengaruh dari variabel atau faktor-faktor lain diluar model.

Setelah dilakukan pengujian dan pembuktian hipotesis, selanjutnya dilakukan analisis untuk mengetahui jawaban pada setiap variabelnya dengan menggunakan metode rata rata jawaban responden, gunan membentuk implikasi penelitian.

Tabel 1.4. Hasil Rata - Rata Jawaban Angket

\begin{tabular}{|l|c|c|c|c|c|c|c|c|c|}
\hline \multirow{2}{*}{ Variabel } & \multicolumn{7}{|c|}{ Butir Pernyataan Instrumen } \\
\cline { 2 - 11 } & 1 & 2 & 3 & 4 & 5 & 6 & 7 & 8 & 9 \\
\hline Disiplin & 1,74 & 2,71 & 1,60 & & 2,71 & 1,61 & & & \\
\hline Tunjangan Kinerja & 2,68 & 1,01 & 3,27 & 2,42 & 2,23 & & & & \\
\hline Prestasi Kerja & 4,63 & 4,30 & & 4,63 & 4,88 & & 4,4 & & 4,5 \\
\hline
\end{tabular}

Sumber: Hasil Perhitungan Tabulasi Penelitian

Guna memudahkan interpretasi dari hasil regresi linier berganda yang digabungkan dengan hasil rata - rata jawaban maka hasil analisis dirangkum dalam gambar rangkuman hasil uji .

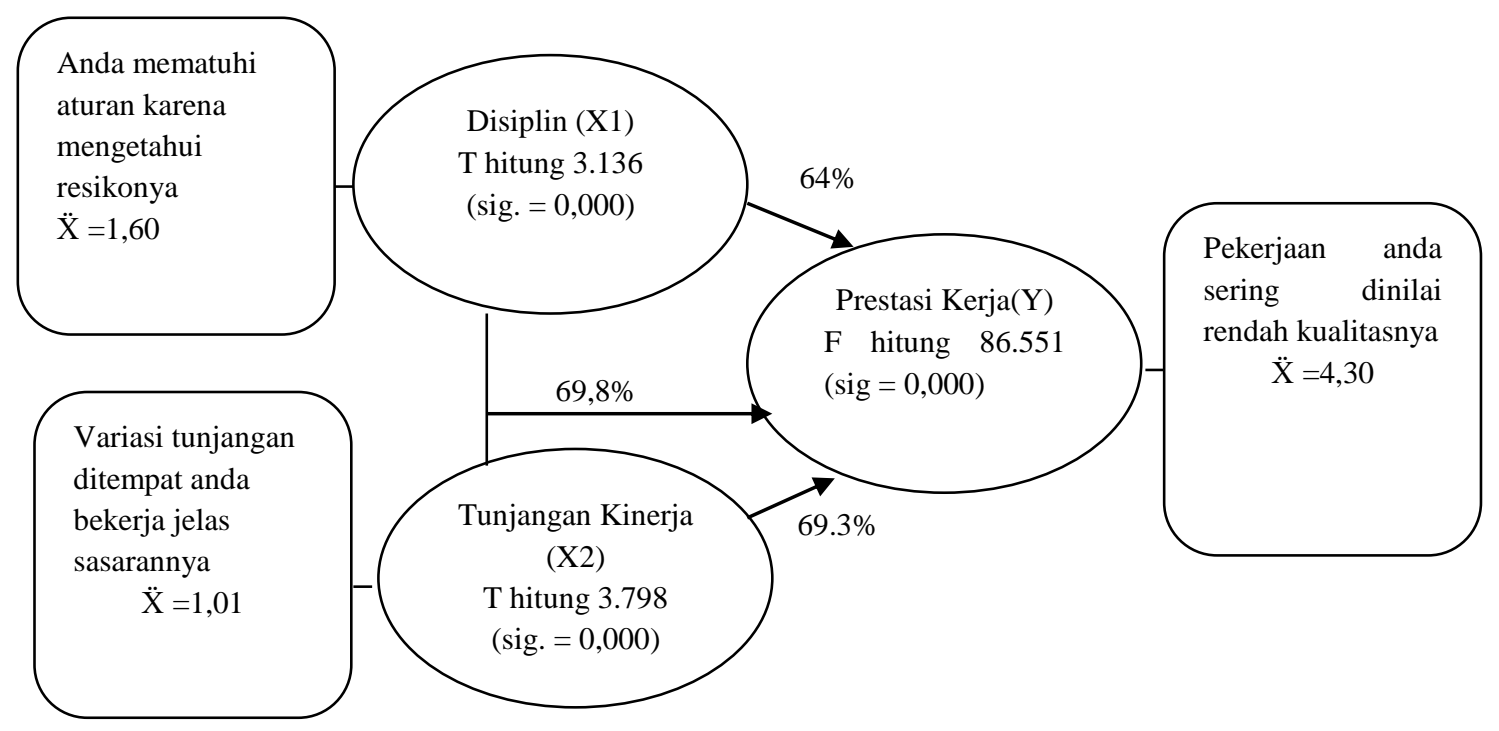

Gambar 2. Rangkuman Hasil Analisis Penelitian

Sumber: Rangkuman Hasil Analisis SPSS

Pembahasan dari hasil rangkuman analisis tersebut maka gambar tersebut dapat diinterpretasikan bahwa Disiplin dan Tunjangan Kinerja memiliki pengaruh yang relatif sedang sebesar 69,8\% terhadap Prestasi Kerja Pegawai Pada Pegawai dengan variabel Tunjangan Kinerja 
sebagai variabel dominan yang mempengaruhi Prestasi Kerja Pegawai sebesar 69,3\%. Pada variabel Disiplin juga didapatkan bahwa butir X13 yaitu Anda mematuhi aturan karena mengetahui resikonya memiliki rata - rata yang paling kecil. Pada Variabel Tunjangan Kinerja didapatkan bahwa butir X22 paling kecil rata - ratanya yaitu pada butir Variasi tunjangan ditempat anda bekerja jelas sasarannya. Kemudian Pada variabel Prestasi Kerja dapatkan bahwa butir Y2 paling kecil rata-ratanya yaitu pada butir Pekerjaan anda sering dinilai rendah kualitasnya. Dari pengolahan data juga didapatkan bahwa masih ada variabel lain yang belum dimasukkan dan memiliki pengaruh pada Prestasi Kerja Pada Pegawai Kecamatan Sukarame.

\section{KESIMPULAN}

Hasil kesimpulan yang telah diuraikan di atas dalam penelitian ini digunakan untuk memberikan implikasi guna mencapai manfaat dari penelitian yang diuraikan sebagai variabel "Disiplin" saran yang dapat diberikan pada Kecamatan Sukarame adalah memperbaiki mental pegawai agar mematuhi aturan karena ada resiko jika melanggarnya, variabel "Tunjangan Kinerja" saran yang dapat diberikan pada Kecamatan Sukarame memperbaiki sistem pemberian variasi tunjangan ditempat bekerja agar jelas sasarannya pada pegawai dengan menyederhanakan perhitungan sistem pemberian tunjangan, kemudian variabel "Prestasi Kerja Pegawai" saran yang dapat diberikan pada Kecamatan Sukarame adalah memperbaiki sistem penilaian pekerjaan yang sering dinilai rendah kualitasnya supaya dapat meningkatkan kualitas kerja pegawai dengan melakukan diskusi dan menciptakan peran pimpinan yang penting di antara pegawai.

\section{DAFTAR PUSTAKA}

Arikunto, Suharmini.2012, Manajemen Penelitian, Jakarta, Rineka Cipta.

Clark, Jhon M. 2007. Human Resource Management. International Edition. The McGraw-Hill Companies, Inc

Cohen, William, 2011, Setiap Pemimpin Harus Baca Buku ini, Jakarta, Tangga Pustaka.

Davis Keith, (2008). Organizational Behavior: Human Behavior at Work. New Delhi : Tata McGraw-Hill.

Dubrin Andrew J. 2015. Leadership. Edisi Ketujuh. (Diterjemahkan oleh: Aris Ananda). Jakarta: Prenada Media.

Handoko, T. Hani. 2015. Manajemen Personalia dan Sumber Daya Manusia. Yoyakarta: BPFE Press.

Hariono, Siswoyo 2007, Metodologi Penelitian Bisnis, Teori dan Aplikasi, Palembang, Badan Penerbit MM UTP.

Haryono, Siswoyo, 2010, Intisari Teori Kepemimpinan, Jakarta, PT. Intermedia Personalia Utama.

Luthan, 2015. Maslow Motivation Hierarchy. International Edition. New York : The McGraw-Hill Companies, Inc

M. Irfan, Islamy, 2012 Prinsip-prinsip Perumusan Kebijaksanaan Negara, Penerbit Bumi Aksara, Jakarta. 2002. 
, Makna Pemerintahan, Tinjauan dari Segi Etika dan Kepemimpinan, PT. Mutiara

Sumber Widya, Jakarta.

Miftah Thoha, 2013. Prilaku Organisasi Konsep Dasar Dan Aplikasinya. Jakarta: Raja Grafindo Persada.

Miriam, Rani, 2009. Pengaruh Gaya Kepemimpinan dan Budaya Organisasi terhadap Kinerja Karyawan Melalui Kepuasan Kerja Karyawan Studi Kasus Pada Kantor Pusat PT. Asuransi Jasa Indonesia (Persero), Jurnal, program Pascasarjana, Semarang, UNDIP.

Masaong, Kadim, Arfan A, Tilomi, 2011, Kepemimpinan Berbasis Multiple Intelligence, Bandung, Alfabeta.

Mintzberg, H., Bruce, A. \& Joseph, L. 2014. Strategy Safari: A Guided Tour through the Wilds of Strategic Management. New York: The Free Press.

Ndraha Taliziduhu, 2009 Ilmu Pemerintahan (Kybernology) Jilid I, II, III,IV dan V BKU Ilmu Pemerintahan Kerjasama IIP-UNPAD, Jakarta.

Pasolong, Harbani. 2010. Kepemimpinan Birokrasi. Bandung: Alfabeta.

Robbins, Stephen P, 2010, Organizational Behavior, New Jersey: Prentice Hall International.

Rivai, Veithzal dan Sagala, 2011, Manajemen Sumber Daya Manusia untuk Perusahaan Dari Teori ke Praktik, Jakarta, Rajawali Press.

Sekaran Uma. 2010, Research Methods For Business, New York :John Wiley \& Sons, Inc.

Siagian Sondang P., 2012. Kiat Meningkatkan Produktivitas Kerja, Cetakan Pertama, , Jakarta: PT. Rineka Cipta.

Sugiyono, 2010 Metode Penelitian Pendidikan, Penerbit Alfabeta, Bandung. 2010.

Universitas Sang Bumi Ruwa Jurai 2014. Pedoman Penulisan Tesis. Bandar Lampung. Universitas Sang Bumi Ruwa Jurai.

Yuniarsih, Suwatno, 2009, Manajemen Sumber Daya Manusia, Bandung, Alfabeta.

Peraturan-Peraturan dan Perundang-undangan : Undang-Undang No. 22 Tahun 1999 tentang Pemerintahan Daerah. UU No. 32 Tahun 2004 jo UU No. 12 Tahun 2008 tentang Perubahan Kedua Atas Undang-Undang Nomor 32 Tahun 2004 Tentang Pemerintahan Daerah. 